\title{
Sedentary Activity Level of Junior High School Students in Surabaya during the Covid 19 Pandemic
}

\author{
Hijrin Fithroni ${ }^{1, *}$ Afif Rusdiawan ${ }^{2,}$ Donny Ardy Kusuma ${ }^{3,}$ Awang Firmansyah ${ }^{4}$ \\ ${ }^{1,2,, 4}$ Department of Health Education and Recreation, Universitas Negeri Surabaya, Indonesia \\ ${ }^{3}$ Department of Sport Coaching Education, Universitas Negeri Surabaya, Surabaya, Indonesia \\ "Corresponding author. Email: hijrinfithroni@unesa.ac.id
}

\begin{abstract}
The purpose of this study was to determine the level of passive activity of Surabaya Junior High School students during the COVID-19 pandemic. This research design is cross-sectional; one hundred fifty-one respondents from SMP 59 Surabaya were recruited as samples in this study. The variable measured in this study is a passive activity in junior high school students in Surabaya. Respondents fill out a questionnaire on a google form taken from the ASAQ instrument to determine sedentary activity level. The results showed that passive activity was in the low category of $95.36 \%$ in SAWd and $79.47 \%$ in SAWe. The high class is only $4.64 \%$ on SAWd and 20.53 on sale. Independent sample t-test also showed significantly different results for sedentary activity on weekdays (SAWd) and weekends (SAWe) $(\mathrm{p}<0.05)$. In conclusion, During the COVID-19 pandemic, the passive movement of junior high school students in Surabaya was still dominant in the low category. However, the time for passive activity on weekends was more significant than on weekdays.
\end{abstract}

Keywords: Sedentary activity, Covid 19, Surabaya, Junior high school.

\section{INTRODUCTION}

At the beginning of 2020, the world was shocked by the coronavirus outbreak (Covid-19), which later infected almost all countries in the world. It is suspected that Covid-19 first appeared in Wuhan [1]. On January 30, 2020, WHO declared Covid-19 a Public Health Emergency of International Concern (PHEIC). The increase in COVID-19 cases is happening quite quickly and is spreading outside the Wuhan area and other countries [2]. The number of infected patients continues to increase significantly at a relatively fast time. On May 26, 2020, 5,370,375 people were infected with the coronavirus, 344,454 people died from 216 countries that were infected [3].

People's behavior during the pandemic has changed, including WFH, everything virtual, transport mode choice, and control access. Previously more as a support for secondary work or recreation, technology has turned into the main work facility [2]. This also has an impact on the education system in Indonesia. During the pandemic, the teaching and learning process is carried out online to avoid the transmission of the covid 19 viruses. Students can interact with teachers using several applications such as classroom, video conference, telephone or live chat, zoom, or WhatsApp group [4].
Although restrictive measures are highly recommended and essential to reduce the spread of COVID-19, they can result in unhealthy behaviors such as a sedentary lifestyle. The closure of schools due to covid 19 and the omission of sports activities in physical education lessons resulted in a decrease in students' physical activity, which resulted in the overall physical health of students [6]. Students undertaking online learning from home should also pay attention to the potential effects of reduced physical activity and increased sedentary behavior [5].

Bahctiar et al. (2020) reported in their research that from 90 respondents, $45.6 \%$ had a low level of physical activity [7]. Then, Dunton et al. (2020) also reported the results of their research that during the pandemic, the sedentary behavior of children living in America increased while their physical activity decreased [6]. Alomari et al. (2020) also reported that there was an increase in sedentary behavior during the COVID-19 pandemic, including watching TV $(72.3 \%)$, using electronics $(82.7 \%)$, and accessing social media (81.9\%) [8].

A sedentary lifestyle is a person's lifestyle that does not meet the standards of physical activity carried out in a day. This pandemic period has resulted in decreased physical activity and more activities that do not require 
much energy. It can be seen that the current tendency of children to play actively outside the home is sitting passively in front of a computer screen or television [9]

According to Aubert et al. (2017), the definition of sedentary behavior is "all activities with an energy expenditure of 1.5 metabolic equivalents (MET) in a sitting position or problem". This includes sitting at leisure, commuting to work, and at work and home [10]. High sedentary activity is characterized by a passive activity carried out $>5$ hours per day [11]

High sedentary activities are at risk for health problems such as obesity and cardiovascular disease [12]. There is a solid relationship between passive activity and obesity. Watching TV, youtube videos, and playing games on smartphones or computers are risk factors for obesity in children and adolescents, especially in this computer age [13]. Obese patients have a high risk of cardiovascular disorders, diabetes mellitus, sleep disorders, hypertension, osteoarthritis, prostate, endometrial and intestinal cancer [14]. So it can be concluded that high sedentary activity will increase the risk of interference with physical health [15].

Based on the explanation above about the importance of physical activity during the pandemic, it is necessary to conduct a study on the level of passive activity during the COVID-19 pandemic.

\section{METHODS}

This research design is cross-sectional. Samples were taken using a purposive technique. The inclusion criteria for study participation included: healthy junior high school students aged 12-16 years old and active students at a school in Surabaya, East Java. Participants complete a questionnaire in google form to determine the level of passive activity. The questionnaire used is the Adolescent Sedentary Activity Questionnaire
(ASAQ). The online survey between July 05, 2021, and July 11, 2021, with 151 respondents.

ASAQ as an instrument in this study measures screen-based activities, reading-based activities, and sitting-based activities, frequency, and duration per activity, then converted into minutes and hours. Sedentary activity data is categorized into the high category of passive activity $>5$ hours (300 minutes) per day and moderate type of sedentary activity 5 hours (300 minutes) per day [16].

To avoid the influence of weekends on sedentary activities, in this study, passive activities are divided into sedentary activities during weekdays, measured on Monday-Friday (SAWd), and sedentary activities during weekends, which are calculated Saturdays-Sundays (SAWd). Data analysis used descriptive test and Mann Whitney test using SPSS 20 software.

\section{RESULTS AND DISCUSSION}

\subsection{Results}

The characteristics of the sample indicate that there are 75 male and 76 female respondents. The mean was not significantly different $(\mathrm{p}>0.05)$ in terms of age, namely $13.92 \pm 0.95$ for boys and $13.94 \pm 0.71$ for girls. The mean of Sedentary Activities on weekdays (SAWd) obtained with the ASAQ instrument showed a value that was not significantly different between male and female students $(\mathrm{p}>0.05)$. This also happened to the results of Sedentary Activities on weekends (SAWe) which showed that the mean value was not significantly different between male and female students $(p>0.05)$. However, when compared the mean results between Sedentary Activities on weekdays (SAWd) and Sedentary Activities on weekends (SAWe), the results show that there is a significant difference with a p-value of $<0.005$. For more details, see table 1

Table 1. Characteristic of research subjects

\begin{tabular}{|c|c|c|c|c|c|}
\hline \multirow{2}{*}{ Variable } & \multicolumn{5}{|c|}{ Mean \pm SD } \\
\cline { 2 - 5 } & Boys $(\mathrm{N}=75)$ & Girls $(\mathrm{N}=76)$ & $\mathrm{P}(\mathrm{sig})$. & $\begin{array}{c}\text { All Gender } \\
(\mathrm{N}=151)\end{array}$ & $\mathrm{P}(\mathrm{sig}$.) \\
\hline Age (year) & $13.92 \pm 0.95$ & $13.94 \pm 0.71$ & 0.736 & $13.93 \pm 0.83$ & \\
\hline SAWd (mins/day) & $113.29 \pm 174.71$ & $177.77 \pm 719.32$ & 0.964 & $146.60 \pm 530.39$ & \multirow{2}{*}{$0.000 *$} \\
\hline SAWe (mins/day) & $219.61 \pm 170.44$ & $296.79 \pm 561.77$ & 0.623 & $259.48 \pm 421.24$ & \\
\hline
\end{tabular}

ignificantly different at $\mathrm{p}<0.05$ using the Mann Whitney test

SAWd= Sedentary Activities on a weekday (Monday-Friday)

SAWd $=$ Sedentary Activities on a weekday (Monday-Friday)
SAWe $=$ Sedentary Activities on the weekend (Saturday-Sunday)

To determine the level of sedentary subjects in the study, the percentage of low and high inactive categories between SAWd and SAWe was calculated, respectively. The passive activity level increases if the sedentary activity value is $>5$ hours/day, and the low if the

stagnant activity value is 5 hours/day [11]. Table 1 showed the percentage result of $95.36 \%$, which is at a low level in SAWd, while in SAWe showed the percentage result of $79.47 \%$. To more clearly see the comparison can be seen in Figure. 
Table 2. Percentage of sedentary activity level category

\begin{tabular}{|c|c|c|c|c|c|c|c|c|c|c|c|c|}
\hline \multirow{2}{*}{$\begin{array}{c}\text { Level } \\
\text { Category }\end{array}$} & \multicolumn{6}{|c|}{ SAWd } & \multicolumn{6}{|c|}{ SAWe } \\
\hline & Boys & $\%$ & Girls & $\%$ & All Gender & $\%$ & Boys & $\%$ & Girls & $\%$ & All Gender & $\%$ \\
\hline Low & 69 & 94.52 & 75 & 96.15 & 144 & 95.36 & 60 & 82.19 & 60 & 76.92 & 120 & 79.47 \\
\hline High & 4 & 5.48 & 3 & 3.85 & 7 & 4.64 & 13 & 17.81 & 18 & 23.08 & 31 & 20.53 \\
\hline
\end{tabular}

SAWd $=$ Sedentary Activities on a weekday (Monday-Friday)

$\mathrm{SAWe}=$ Sedentary Activities on the weekend (Saturday-Sunday)

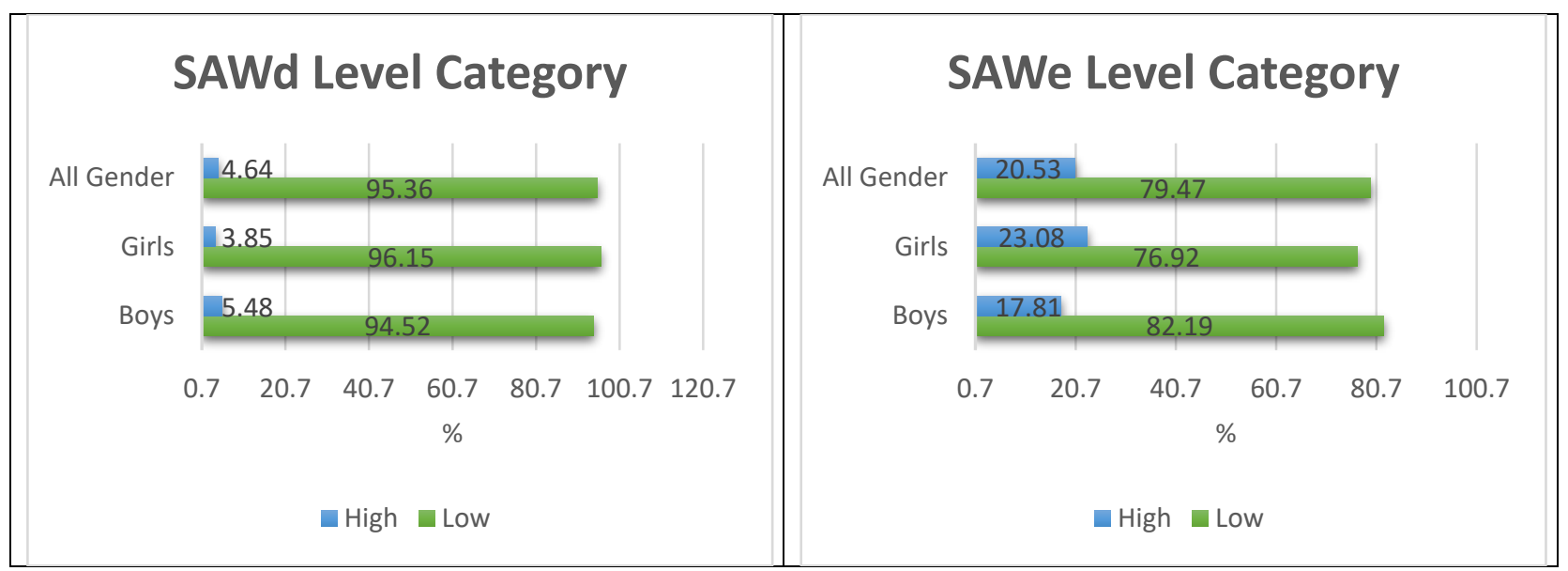

Figure 1. Level category of SAWd and SAWe

Table 3. Distribution of sedentary activity between SAWd and SAWe

\begin{tabular}{|c|c|c|c|}
\hline \multirow[b]{2}{*}{ Activity } & \multicolumn{2}{|c|}{ Mean \pm SD } & \multirow{2}{*}{$\begin{array}{c}P \\
\text { (sig.) }\end{array}$} \\
\hline & $\begin{array}{l}\text { SAWd } \\
\text { (mins/day) }\end{array}$ & $\begin{array}{c}\text { SAWe } \\
\text { (mins/day) }\end{array}$ & \\
\hline Watching television & $115.91 \pm 519.36$ & $118.07 \pm 550.49$ & 0.555 \\
\hline $\begin{array}{l}\text { Watching videos (DVD, } \\
\text { videos on youtube, etc.) }\end{array}$ & $63.86 \pm 88.68$ & $71.65 \pm 250.09$ & 0.324 \\
\hline $\begin{array}{l}\text { Playing games on your } \\
\text { phone, laptop, computer, or } \\
\text { tablet }\end{array}$ & $85.45 \pm 126.94$ & $77.85 \pm 107.12$ & 0.499 \\
\hline $\begin{array}{l}\text { Reading } \\
\text { novels/comics/magazines }\end{array}$ & $36.05 \pm 39.92$ & $43.46 \pm 124.98$ & 0.914 \\
\hline Learning/doing homework & $53.60 \pm 62.63$ & $45.73 \pm 34.16$ & 0.486 \\
\hline Additional learning/tutoring & $40.26 \pm 41.72$ & $36.66 \pm 35.62$ & 0.547 \\
\hline $\begin{array}{l}\text { Using a motorized vehicle } \\
\text { in mobility }\end{array}$ & $37.76 \pm 63.28$ & $36.52 \pm 44.72$ & 0.664 \\
\hline Using social media & $75.01 \pm 131.29$ & $61.99 \pm 104.54$ & 0.539 \\
\hline $\begin{array}{l}\text { Playing music / listen to } \\
\text { music }\end{array}$ & $30.65 \pm 31.75$ & $30.03 \pm 29.78$ & 0.855 \\
\hline
\end{tabular}

Table 3 above shows the distribution of passive activity between SAWd and SAWe. The results showed that all activities showed no significant difference between SAWd and SAWe ( $\mathrm{p}>0.05)$.

\subsection{Discussion}

Sedentary activities such as screen time, sitting, eating, and sleeping are closely related to children's health [17][18] [19]. Screen time such as playing games on the computer, watching TV, watching videos for a long duration can reduce a child's fitness level and increase the risk of childhood obesity [17][19]. However, currently, sedentary activity is increasing after the announcement of the COVID-19 pandemic by the WHO in March 2020, which led to social distancing policies such as closing public facilities, schools, fitness places, recreation areas, causing physical activity to decline [20].

This study indicates that the results of passive activity during the COVID-19 pandemic between SAWd and SAWe were significantly different $(p<0.05)$. However, there was no significant difference between girls and boys ( $>>0.05)$ (Table 1), according to research by Juren et al. (2020), which states that there is no significant difference in sitting time between genders [21]. Another study noted that sedentary activity between weekends and weekdays was significantly different, but differences were not shown in gender [22][23]. When viewed from the mean value, girls have a longer sedentary time than boys. This is because boys are more active in physical activity while girls spend more time sitting [24].

The percentage level of sedentary activity in all gender SAWd groups shows a value of $95.36 \%$ in the low category and the rest in the high sort. Meanwhile, the same group showed $79.47 \%$ in the low class and $20.53 \%$ in the high category. This percentage also indicates that the same group has a higher sedentary activity category than the SAWd group. Like statement McMurray et al. (2016), which states that on holidays (weekends), activity will decrease so that sedentary activity increases [25]. In general, on weekends, 50\% $80 \%$ of the day is spent doing passive activities [26] The weekend is a time to gather with family. Differences in age and interests between parents and 
children cause physical activity not to be done together [27].

Table 3 showed no significant difference between the nine activity items that describe sedentary activities on weekdays and weekends ( $>>0.05)$. However, if we look at the percentage, it has a high value in watching tv and watching videos on weekends. For children, watching $\mathrm{tv}$ is an activity that significantly contributes to screening time [28]. Excessive screen time is strongly associated with an increase in children's sedentary activity [29]. Factors causing excessive screen time include the digital environment, parental behavior, and government regulations [30]. Low parental education has a relationship with increased sedentary activity through high screen time [31]. A study also states that screen time gradually increases as a child gets older [32].

Excessive screen time will lead to an increased risk of obesity, poor fitness, poor cognitive development, and interfere with psychosocial health [32]. In addition, decreased physical activity and increased screen time will reduce the quality of children's sleep [33].

\section{CONCLUSION}

During the COVID-19 pandemic, the level of passive activity of junior high school students in Surabaya was still dominant in the low category, namely $95.36 \%$ on weekdays and $79.47 \%$ on weekends. The high level of passive activity on weekends is influenced by screen time. Further research is expected to examine the factors that cause an increase in sedentary activities, such as the living environment, parental characteristics, and government regulations.

\section{ACKNOWLEDGMENTS}

Thank you to SMPN 59 Surabaya for being the subject of this research.

\section{REFERENCES}

[1] Kemenkes, "Pedoman kesiapan menghadapi COVID-19," in Pedoman kesiapan menghadapi COVID-19, 2020, pp. 0-115.

[2] E. S. Rosali, “Aktifitas Pembelajaran Daring Pada Masa Pandemi Covid-19 Di Jurusan Pendidikan Geografi Universitas Siliwangi Tasikmalaya," Geogr. Sci. Educ. J., vol. 1, no. 1, pp. 21-30, 2020.

[3] H. Wismanadi, S. Sulistyarto, P. Juniarto, F. Kafrawi, A. Hakim, and A. Rusdiawan, "Buku Saku Olahraga Pada Masa Pandemik Covid 19," Jendela Olahraga, vol. 6, no. 2, pp. 50-58, 2021, doi: $10.26877 /$ jo.v6i2.7956.

[4] W. A. F. Dewi, "Dampak COVID-19 terhadap
Implementasi Pembelajaran Daring di Sekolah Dasar," Edukatif J. Ilmu Pendidik., vol. 2, no. 1, pp. 55-61, 2020, doi: 10.31004/edukatif.v2i1.89.

[5] C. Zheng, W. Y. Huang, S. Sheridan, C. H. P. Sit, X. K. Chen, and S. H. S. Wong, "Covid-19 pandemic brings a sedentary lifestyle in young adults: A cross-sectional and longitudinal study," Int. J. Environ. Res. Public Health, vol. 17, no. 17, pp. 1-11, 2020, DOI: 10.3390/ijerph17176035.

[6] G. F. Dunton, B. Do, and S. D. Wang, "Early effects of the COVID-19 pandemic on physical activity and sedentary behavior in children living in the US," BMC Public Health, vol. 20, no. 1, pp. 1-13, 2020, DOI: 10.1186/s12889-020-09429-3.

[7] F. Bachtiar, Condrowati, D. Utari, and F. T. Maharani, "Physical Activity Levels of Adults During Covid-19 Quarantine in Indonesia: A Cross-Sectional Descriptive Study," vol. 30, no. Ich, pp. 267-273, 2020, DOI: 10.2991/has.k.201125.047.

[8] M. A. Alomari, O. F. Khabour, and K. H. Alzoubi, "Changes in physical activity and sedentary behavior amid confinement: The bestcovid-19 project," Risk Manag. Healthc. Policy, vol. 13, pp. 1757-1764, 2020, DOI: 10.2147/RMHP.S268320.

[9] D. A. Gentile, "The Multiple Dimensions of Video Game Effects," Child Dev. Perspect., vol. 5, no. 2, pp. 75-81, 2011, DOI: 10.1111/j.17508606.2011.00159.x.

[10] M. S. Tremblay et al., "Sedentary Behavior Research Network (SBRN) - Terminology Consensus Project process and outcome," Int. J. Behav. Nutr. Phys. Act., vol. 14, no. 1, pp. 1-17, 2017, DOI: 10.1186/s12966-017-0525-8.

[11] F. D. Andriyani, S. J. H. Biddle, N. I. Arovah, and K. de Cocker, "Physical activity and sedentary behavior research in Indonesian youth: A scoping review," Int. J. Environ. Res. Public Health, vol. 17, no. 20, pp. 1-15, 2020, DOI: 10.3390/ijerph17207665.

[12] S. Mora, I.-M. Lee, J. E. Buring, and P. M. Ridker, "Association of Physical Activity and Body Mass Index With Novel and Traditional Cardiovascular Biomarkers in Women," J. Am. Med. Assoc., vol. 295, no. 12, pp. 1412-1419, 2006, Accessed: August 07, 2021. [Online]. Available: https://jamanetwork.com/.

[13] J. Salmon, M. S. Tremblay, S. J. Marshall, and C. Hume, "Health risks, correlates, and interventions 
to reduce sedentary behavior in young people," Am. J. Prev. Med., vol. 41, no. 2, pp. 197-206, 2011, DOI: 10.1016/j.amepre.2011.05.001.

[14] T. Taufikkurrachman, A. N. Wardathi, A. Rusdiawan, R. S. Sari, and B. Kusumawardhana, "Olahraga Kardio dan Tabata: Rekomendasi Untuk Menurunkan Lemak Tubuh Dan Berat Badan," Jendela Olahraga, vol. 6, no. 1, pp. 197212, 2021, doi: 10.26877/jo.v6i1.7469.

[15] M. Inyang and O.-O. Stella, "Sedentary Lifestyle: Health Implications," J. Nurs. Heal. Sci. e-ISSN, vol. 4, no. 2, pp. 20-25, 2015, DOI: 10.9790/1959-04212025.

[16] D. Hartanti and D. R. M. Mawarni, "Hubungan Konsumsi Buah Dan Sayur Serta Aktivitas Sedentari Terhadap Kebugaran Jasmani Kelompok Usia Dewasa Muda," Sport Nutr. J., vol. 2, no. 1, pp. 1-9, 2020, doi: 10.1016/j.sasoi.2013.12.010.

[17] V. Carson et al., "Systematic review of sedentary behavior and health indicators in school-aged children and youth: An update," Appl. Physiol. Nutr. Metab., vol. 41, no. 6, pp. S240-S265, 2016, DOI: 10.1139/apnm-2015-0630.

[18] G. Cardon et al., "Health-Related Behaviours in Normal Weight and Overweight Preschoolers of a Large Pan-European Sample: The ToyBoxStudy," 2016, DOI: 10.1371/journal.pone.0150580.

[19] A. G. LeBlanc et al., "Systematic review of sedentary behavior and health indicators in the early years (aged 0-4 years)," Appl. Physiol. Nutr. Metab., vol. 37, no. 4, pp. 753-772, 2012, DOI: 10.1139/H2012-063.

[20] P. S. C. P. M. A. Ms. K. T. C. P. J. M. M. C. S. B. M. Ms. Leigh M. Vanderloo, "Vanderloo2020," J. Dev. Behav. Pediatr., vol. 41, no. 5, pp. 19-20, 2020.

[21] Y. U. Juren, K. G. Soh, K. L. Soh, S. L. Ong, M. K. Siswantoyo, and J. Sunardi, "Comparing Sitting Time Between Male And Female Undergraduate Students During Weekdays And Weekends," Eur. J. Mol. Clin. Med., vol. 7, no. 3, pp. 2515-8260, 2020.

[22] R. Jago et al., "Cross-sectional associations between the screen-time of parents and young children: Differences by parent and child gender and day of the week," Int. J. Behav. Nutr. Phys. Act., vol. 11, no. 1, pp. 1-8, 2014, DOI: 10.1186/1479-5868-11-54.

[23] D. Sigmundová and E. Sigmund, "Weekday- weekend sedentary behavior and recreational screen time patterns in families with preschoolers, schoolchildren, and adolescents: Cross-sectional three cohort study," Int. J. Environ. Res. Public Health, vol. 18, no. 9, 2021, DOI: 10.3390/ijerph18094532.

[24] Y. Y. Chan et al., "Prevalence and correlates of physical inactivity among older adults in Malaysia: Findings from the National Health and Morbidity Survey (NHMS) 2015," Arch. Gerontol. Geriatr., vol. 81, no. November 2018, pp. 74-83, 2019, doi 10.1016/j.archger.2018.11.012.

[25] R. G. McMurray et al., "Relationships of physical activity and sedentary time in obese parent-child dyads: A cross-sectional study," BMC Public Health, vol. 16, no. 1, pp. 1-8, 2016, DOI: 10.1186/s12889-016-2795-5.

[26] J. L. Thompson, R. Jago, R. Brockman, K. Cartwright, A. S. Page, and K. R. Fox, "Physically active families - de-bunking the myth? A qualitative study of family participation in physical activity," Child. Care. Health Dev., vol. 36, no. 2, pp. 265-274, 2010, DOI: 10.1111/j.1365-2214.2009.01051.x.

[27] E. Roos, S. Sarlio-Lähteenkorva, T. Lallukka, and E. Lahelma, "Associations of work-family conflicts with food habits and physical activity," Public Health Nutr., vol. 10, no. 3, pp. 222-229, 2007, DOI: $10.1017 / \mathrm{S} 1368980007248487$.

[28] V. Flynn, G. Foley, S. B. Berkeley, and A. L. Mendelsohn, "Media Content and Externalizing Behaviors," Ambul. Pediatr., vol. 7, no. 3, pp. 232-238, 2007.

[29] N. Pearson and S. J. H. Biddle, "Sedentary behavior and dietary intake in children, adolescents, and adults: A systematic review," Am. J. Prev. Med., vol. 41, no. 2, pp. 178-188, 2011, DOI: 10.1016/j.amepre.2011.05.002.

[30] N. Kaur, M. Gupta, P. Malhi, and S. Grover, "Screen Time in Under-five Children," Indian Pediatr., vol. 56, no. 9, pp. 773-788, 2019, DOI: 10.1007/s13312-019-1638-8.

[31] G. R. de Sousa and D. A. S. Silva, "Comportamento sedentário baseado em tempo de tela: Prevalência e fatores sociodemográficos associados em adolescentes," Cienc. e Saude Coletiva, vol. 22, no. 12, pp. 4061-4072, 2017, doi: 10.1590/1413-812320172212.00472016.

[32] S. E. Barber, B. Kelly, P. J. Collings, L. Nagy, T. Bywater, and J. Wright, "Prevalence, trajectories, 
and determinants of television viewing time in an ethnically diverse sample of young children from the UK," Int. J. Behav. Nutr. Phys. Act., vol. 14, no. 1, pp. 1-11, 2017, DOI: 10.1186/s12966-0170541-8.

[33] X. Janssen, A. Martin, A. R. Hughes, C. M. Hill, G. Kotronoulas, and K. R. Hesketh, "Associations of screen time, sedentary time and physical activity with sleep in under 5s: A systematic review and meta-analysis," Sleep Med. Rev., vol. 49, no. February 2020, p. 101226, 2020, DOI: 10.1016/j.smrv.2019.101226. 